\title{
Effect of Heat Treatment and Types of Bacteria on Corrosion Resistance of Steel Materials (API 5L and ASTM A53) in Marine Environment
}

\author{
Herman Pratikno, ${ }^{\mathrm{a},}$, Harmin S Titah ${ }^{\mathrm{b}}$ and Febrian R Sastradimaja ${ }^{\mathrm{c}}$ \\ a) Associate Professor, Department of Ocean Engineering, Institut Teknologi Sepuluh Nopember, Kampus ITS - Sukolilo, Surabaya \\ 60111, Indonesia \\ b) Assistant Professor, Department of Environmental Engineering, Institut Teknologi Sepuluh Nopember, Kampus ITS - Sukolilo, \\ Surabaya 60111, Indonesia \\ c) Student, Department of Ocean Engineering, Institut Teknologi Sepuluh Nopember, Kampus ITS - Sukolilo, Surabaya 60111, Indonesia \\ * Corresponding author: hermanp@oe.its.ac.id
}

\begin{abstract}
Corrosion is the result of damage to material degradation through a chemical or electrochemical reaction spontaneously and causes a decrease in the quality of the material. One of the causes of corrosion is the presence of bacteria on the material. The danger posed by corrosion is fatality, especially on offshore platforms, namely cessation of production at offshore rigs. This study is an experiment using material carbon steel API $5 L$ Grade B and ASTM A53 commonly used as a base for the manufacture of subsea pipelines. Material to be heat-treated before immersion for corrosion test in artificial seawater (salinity 35\%o), which have been added with bacteria and without bacteria. The method used in measuring the rate of corrosion steel data is the weight loss. The highest corrosion rate of the original material ASTM A53 and API $5 L$ with the addition of $T$. ferrooxidans bacteria are, respectively, 3.63 mpy and 3.50 mpy. While the lowest corrosion rate of ASTM A53 and API $5 \mathrm{~L}$ both with heat treatment but without adding bacteria are 2.33 mpy and 2.01 mpy. This indicates that the steel API 5 L have high levels of corrosion resistance, better than ASTM A53 in the marine environment with bacteria or without bacteria.
\end{abstract}

Keywords: corrosion, bio-corrosion, bacteria, heat treatment, API $5 L$ Grade B, ASTM A53

\section{INTRODUCTION}

Corrosion is the result of damage to material degradation through a chemical or electrochemical reaction spontaneously, which causes a decrease in the quality of the material. The rate of corrosion in a neutral environment is normally 1.0 mpy or less. In addition to the water there are several factors that affect the rate of corrosion, including gas content and soluble solids, temperature, material selection, $\mathrm{pH}$, bacteria [1]

As stated by Rheinheimer [2], heterotrophic bacteria are biotic component in the marine ecosystem function as decomposers to produce minerals - minerals as nutrients. In Indonesia, the spread of bacteria decomposing at sea is uneven. This is due to factors such as source of nutrients, water depths and habitats in marine ecosystems (rivers, lakes, estuaries, and mangroves, shallow marine and deep sea). In addition to the factors mentioned above it is also suggested that physical factors such as ocean currents, tides, turbulence, waves and temperature can affect the distribution of heterotrophic bacteria in marine ecosystems.

Microorganisms that affect the corrosion process is divided into two types: aerobic and anaerobic bacteria. The bacterium forms a colony on the surface of the metal to place their lives. The colony forming a layer (biofilm) on the surface of the material so that the material becomes corroded as a result of the activity of the microorganisms living. In this respect the corrosion brought about the bacteria or microorganism is termed as bio-corrosion.

Bacteria capable of degrading metal in the sea through corrosion, among others Thiobacillus (T.) ferrooxidans, T. thiooxidans, Pseudomonas fluorescens, P. putida, Bacillus licheniformis, and B.Cereus. In the case of Indonesian seas where the majority are geographically shallow waters, according to the research by Irianto and Hendrati [3], the type of bacteria in existence are P. fluorescens, E. coli, T. ferrooxidans.

Bio-corrosion is a major problem for the petroleum industry, causes corrosion in piping under the sea as well as on offshore platforms. Approximately 20-30\% of the incidence of corrosion related to the activity of microorganisms. According to Ugochukwu and Sunday [4], the activities of microorganisms affect the integrity, safety and reliability of pipelines for petroleum operations.

In 2011, the annual cost of all forms of corrosion for the oil and gas industry is estimated to reach $\$ 13.4$ billion, in which bio-corrosion accounted for about $\$ 2$ billion [5]. Given the magnitude of the cost of the repairs due to 
corrosion, it is therefore necessary in the design of subsea pipelines for oil and gas industry to conduct appropriate material selection and proper material treatment.

\section{MATERIALS AND METHODS}

Research procedures ranging from the preparation stage of the test specimen, the test media preparation, through corrosion testing are as described below.

\subsection{Preparation of Specimens}

The specimens used in the current experimental study are made of ASTM A53 and API 5L grade B steel pipes. Preparation of the specimens includes the following five steps.

Cutting Material. According to the American Society of Mechanical Engineers (ASME), the material must be cut with area $4 \mathrm{~cm}^{2}$. In this study as the steel pipe material is a cylindrical then it must be first rolled into a flat plate then cut into pieces with a size of $20 \mathrm{~mm} \times 20 \mathrm{~mm} \times 3 \mathrm{~mm}$, as shown in Fig. 1.

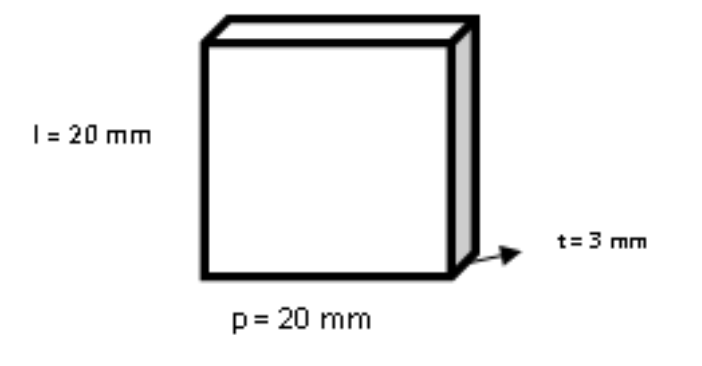

Figure 1. The dimensions of the test specimen

Hardening Process. Furnace as depicted in Fig. 2 is prepared at a temperature of $800^{\circ} \mathrm{C}$. At this temperature the material, which is low carbon steel (carbon content of 0.5), has entered the austenite phase. Namely solid solution phase interstitial between carbon and iron that have the hardest on the material properties. This refers to the study by Pratikno [6] about the process of austempering steel, followed by a rapid cooling in the water (quenching). This results in a rapid cooling rate of decomposition austenite to martensite phase which has a strong but brittle nature [7].

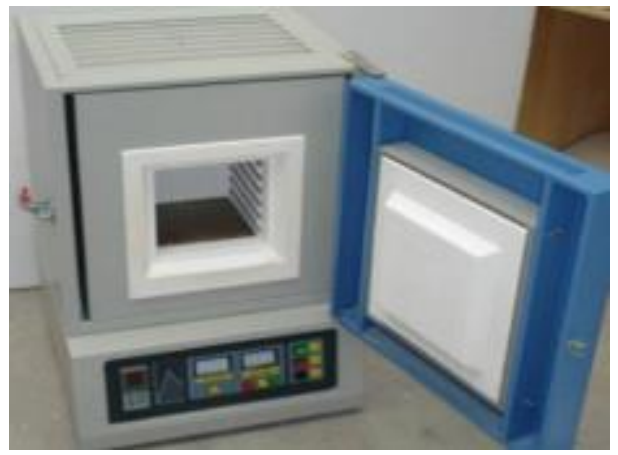

Figure 2. Furnace (stove)
Hardness Testing Process. Hardness testing is conducted by implementing Brinell hardness tester exhibited in Fig. 3. The standard procedure requires the use of balls with a diameter of $10 \mathrm{~mm}$ and a load of 3,000 $\mathrm{kg}$ for testing ferrous metals, or $500 \mathrm{~kg}$ for non-ferrous metals. For ferrous metals, indentation time is usually about 10 seconds while for metals non-ferrous approximately 30 seconds.

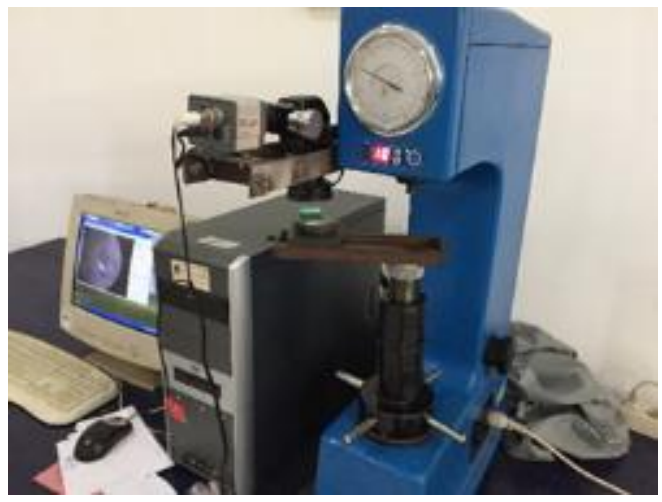

Figure 3. Brinell hardness tester

Pickling Process. Pickling is a step conducted to remove scale, coating layer, a layer that has been corroded, and other crust stuck to the specimen. For this the specimen is immersed for 3 minutes in a solution of $\mathrm{HCl}$.

Cleaning and Weighing. Refining the surface of the specimen is made by using sandpaper number \# 120. Sanding aims to eliminate the crust and smooth the surface of the specimen. After washing with water and wipes, the specimens were weighed with an analytical balance environmental remediation in the laboratory, portrayed in Fig. 4, to determine the initial weight of the specimen.

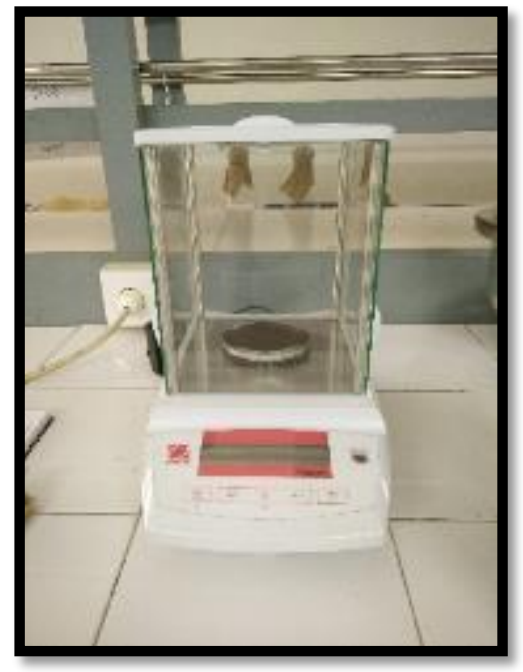

Figure 4. Analytical scales for weighing 


\subsection{Preparation of Bacteria}

Preparation of test bacteria carried out by inoculation back stock bacteria which has been selected. Inoculation was done by using plate streaking on a suitable medium [8]. The bacteria used for testing bio-corrosion are those alive in approximately 24 hours [5].

This study uses three bacteria, namely, Escherechia (E.) Coli, and Thiobacillus (T.) ferrooxidans. Two stages of bacteria preparation, include:

a. Stages re-growth of bacterial isolates (bacterial growth back). That is the stage at which heifers Bacteria grown in media Nutrient Agar and bred before being transferred to Nutrient Broth media.

b. Stages of bacterial inoculation (transfer of bacteria to the test medium). This stage is the bacteria of Nutrient Broth was transferred to media corrosion test, ie artificial seawater.

\subsection{Preparation of Test Solution}

This research used a chemical solution instead of sea water with a salinity of $35 \%$, exhibited in Fig. 5. Salinity of 35\% is the salinity in the ocean of medium depths, wherein the microorganism commonly found at this depth, including bacteria.

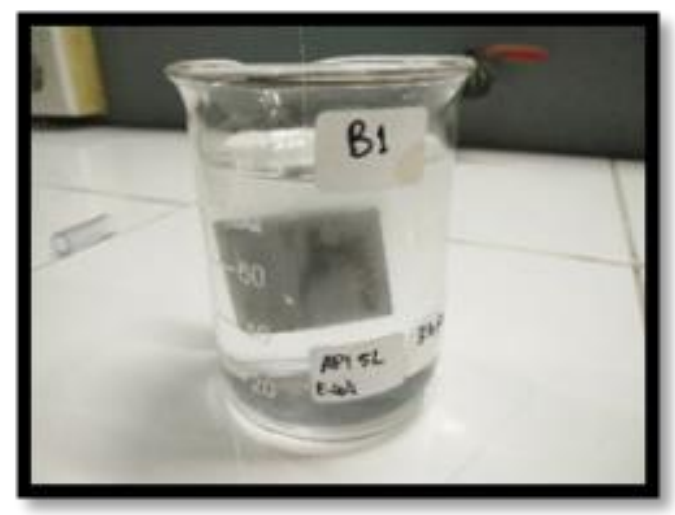

Figure 5 Immersion material on media bio-corrosion

In the soaking test (immersion test) laboratories scale, based on ASTM G31-72 [7], the amount of volume of the solution for a minimum immersion is:

$$
\text { Solution } \mathrm{Vol}=(0.2 \text { to } 0.4) \times \text { surface area }
$$

Based on the existing formula and the dimensions of specimens which have been measured previously, it can be calculated the amount of the volume of solution used in the test:

$$
\text { Area } \quad \begin{aligned}
& =(2 \times \mathrm{p} \times 1)+(2 \times \mathrm{p} \times \mathrm{t})+(2 \times 1 \times \mathrm{t}) \\
& =(2 \times 20 \times 20)+(2 \times 20 \times 3)+(2 \times 203) \\
& =1040 \mathrm{~mm} 2
\end{aligned}
$$

$$
\begin{aligned}
\text { Solution Volume } & =(0.2 \text { s.d. } 0.4) \times \text { Surface Area } \\
& =(0.2 \times 1040) \text { s.d. }(0.4 \times 1040) \\
& =208 \mathrm{ml} \text { s.d. } 416 \mathrm{ml}
\end{aligned}
$$

\begin{tabular}{|c|c|}
\hline Solution & Consentrationg $\mathrm{L}^{-1}$ \\
\hline $\mathrm{NaCl}$ & 24.53 \\
\hline $\mathrm{MgCl}_{2}$ & 5.20 \\
\hline $\mathrm{Na}_{2} \mathrm{SO}_{4}$ & 4.09 \\
\hline $\mathrm{CaC}_{2}$ & 1.16 \\
\hline $\mathrm{Kd}$ & 0.695 \\
\hline $\mathrm{NaHCO}_{3}$ & 0.201 \\
\hline $\mathrm{KBr}$ & 0.101 \\
\hline $\mathrm{H}_{3} \mathrm{BO}_{3}$ & 0.027 \\
\hline $\mathrm{SrCl}_{2}$ & 0.025 \\
\hline $\mathrm{NaF}$ & 0.003 \\
\hline $\mathrm{Ba}\left(\mathrm{NO}_{3}\right)_{2}$ & 0.0000994 \\
\hline $\mathrm{Mn}\left(\mathrm{NO}_{3}\right)_{2}$ & 0.0000340 \\
\hline $\mathrm{Cu}\left(\mathrm{NO}_{3}\right)_{2}$ & 0.0000308 \\
\hline $\mathrm{Zn}\left(\mathrm{NO}_{3}\right)_{2}$ & 0.0000096 \\
\hline $\mathrm{Pb}\left(\mathrm{NO}_{3}\right)_{2}$ & 0.0000066 \\
\hline $\mathrm{AgNo}_{3}$ & 0.00000049 \\
\hline
\end{tabular}

The chemical composition of sea water replacement is in accordance with ASTM D1141-90, 1994 [9]. The chemical composition of the solution can be seen in Table 1 .

Table 1. Chemical composition of sea water substitute (ASTM D1141-90)

\subsection{Bio-Corrosion Testing Process}

The bio-corrosion tests were conducted by the resilience bio-corrosion treatment variations, namely:

a. Without the influence of bacteria. That is in the form of corrosion test of the resilience of the marine environment without the addition of bacteria.

b. With the addition of bacteria. This experiment will compare the rate of corrosion on each test specimen in $35 \%$ salinity of the marine environment with the addition of some types of bacteria.

\subsection{Cleaning Specimen and Weighing After Corroded}

After the corrosion test, cleaning is carried out by pouring water and dried with a hair dryer so that the remains of the missing material corrosion and water attached becomes dry. After the specimen is cleaned, then the weighing is done with an analytical balance. This is done with the aim of obtaining data on the weight lost during the corrosion process.

\subsection{Micro Structure Observation}

Specimens need to be polished with a machine polisher before micro structure observation is carried out under a microscope, shown in Fig. 6. Sandpaper grades which are employed to polish cover \#80, \#120, \#240, \#320, \#500, $\# 600$, \#800, \#1000, \#1200, \#1500, and \#2000. 


\subsection{Corrosion Rate Calculations}

After immersion into the solution and cleaned, the specimen is then weighed. Following this, the calculation of corrosion rate is made by using the method of weight loss. Corrosion rate calculation formula by using the weight loss method in accordance with ASTM G1-72 [10], is expressed as:

$$
\text { Corrosion Rate }=\frac{K \times W}{D \times A \times T}
$$

Where $W$ is losing weight (mg), $K$ is constant (mpy equals to $\left.3.45 \times 10^{6}\right), D$ is density of the test specimen $\left(\mathrm{g} / \mathrm{cm}^{3}\right), A$ is area of the corroded surface $\left(\mathrm{m}^{2}\right)$ and $T$ is time of exposure (hours).

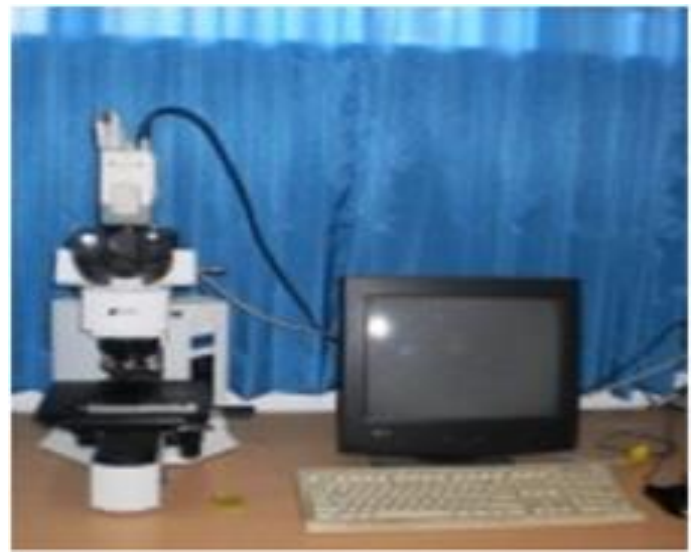

Figure 6. Optic microscope

\section{ANALYSIS AND DISCUSSION}

\subsection{Results of Material Preparation}

Material preparation has been conducted by following the procedure described in sub-section 2.1. Base materials were cut into square specimens and then grouped into the nontreated (original) and heat-treated. The latter specimens were heated and then quenched, as shown in Fig. 7.

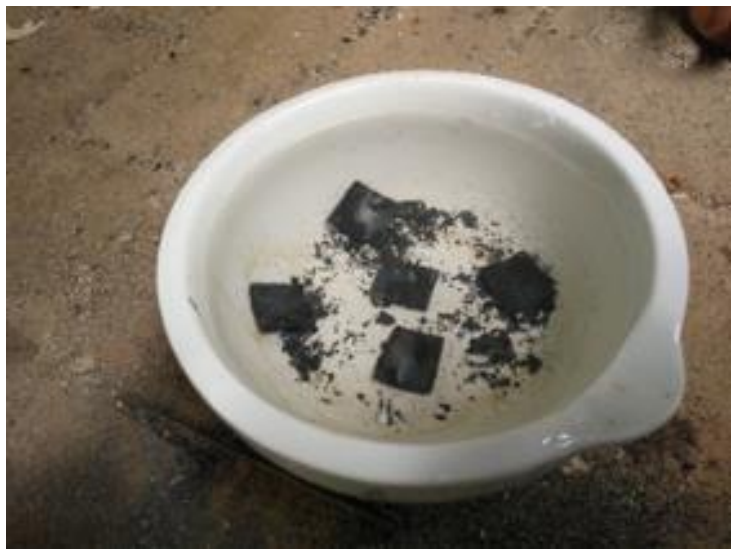

Figure 7. The process of rapid cooling water media
The original and heat-treated specimens were further processed for hardness testing by employing the Brinell hardness tester. Results of the hardness testing are contained in Table 8. The results demonstrate that ASTM A53 class material possesses higher hardness characteristic in comparison to API 5L. Additionally, the effect of heat treatment in increasing the material hardness is obvious. In the case of API 5L class material the heat treatment increases the hardness by about $19 \%$, while in the case of ASTM A53 by some $15 \%$.

Table 2. Hardness Test Material Test

\begin{tabular}{|l|l|c|}
\hline \multicolumn{1}{|c|}{ Name } & \multicolumn{1}{|c|}{ Treatment } & $\begin{array}{c}\text { Result } \\
\text { (Brinell } \\
\text { scale) }\end{array}$ \\
\hline \multirow{2}{*}{ API 5L } & Original & 126 \\
\hline \multirow{2}{*}{ ASTM A53 } & Heat Treatment & 150 \\
\hline & Original & 148 \\
\hline & Heat Treatment & 171 \\
\hline
\end{tabular}

\subsection{Results the Breeding of Bacteria (Re-growth of Bacterial Isolates)}

Table 3 explains the comparison of the characteristics of 3 types of bacteria after the breeding is performed. These include color, pattern, density, colony formation and the acid produced.

Table 3. Results of the breeding of bacteria

\begin{tabular}{|c|c|}
\hline Nanua & Keterangan \\
\hline Escherichia Coli & 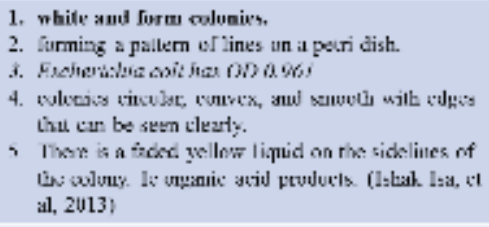 \\
\hline Fredodomonas Fianesctins & 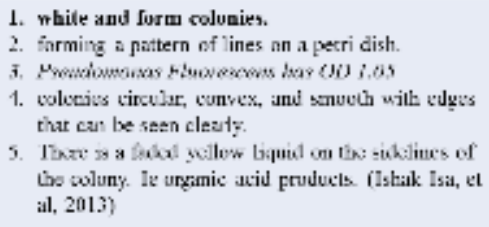 \\
\hline Thiobaciliss Ferrooxidans & 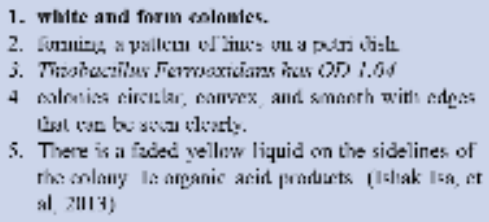 \\
\hline
\end{tabular}




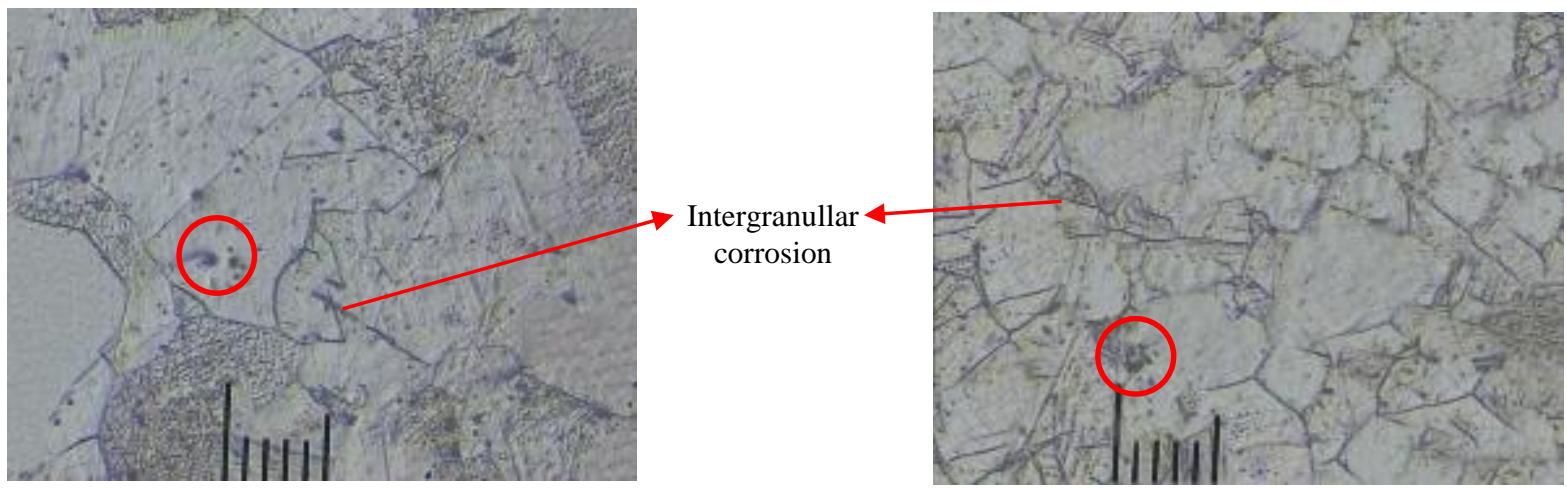

(i)

(iv)

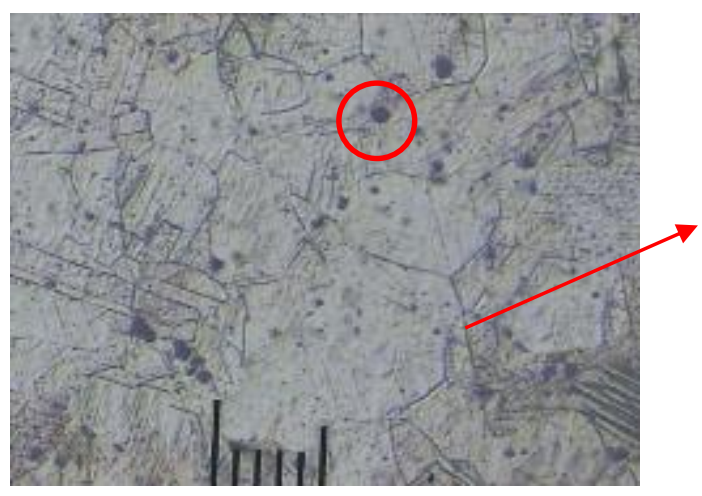

(ii)

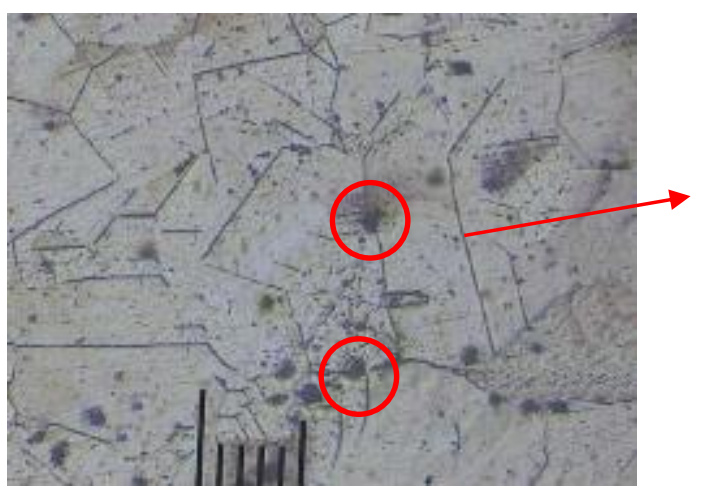

(iii)

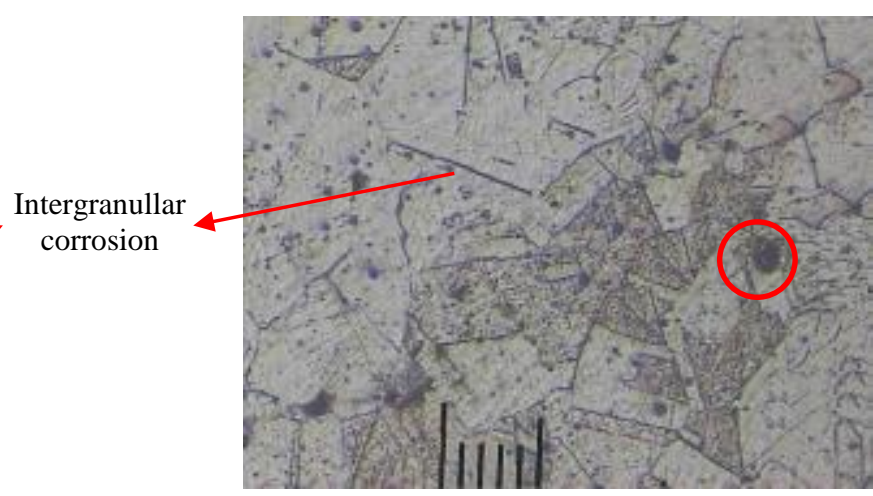

(v)

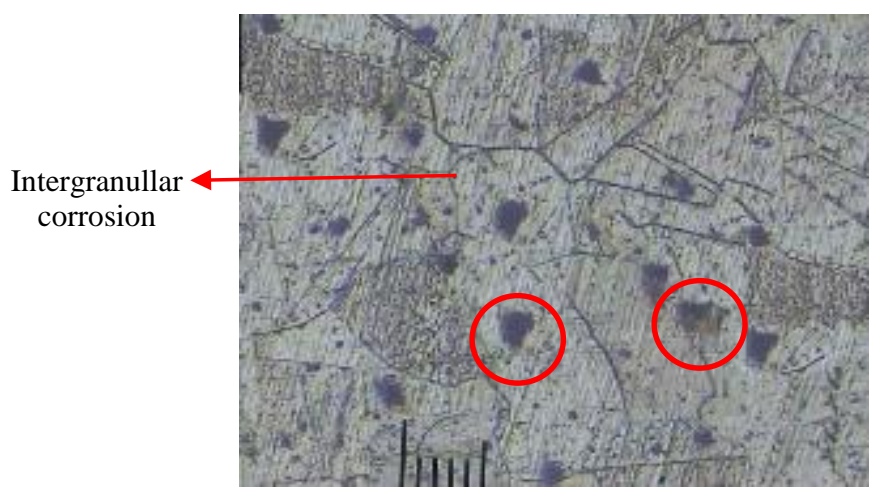

(vi)

Figure 10. (i) Micro photograph ASTM A53 HT without the addition of bacteria (ii) Micro photograph ASTM A53 HT with the addition of T. Ferrooxidans

(iii) Micro photograph ASTM A53 ori with the addition of T. Ferrooxidans

(iv) Micro photograph API 5L HT without the addition of bacteria

(v) Micro photograph HT API 5L with the addition of T. Ferrooxidans

(vi) Micro photograph ori API 5L with the addition of T. Ferrooxidans 


\subsection{Results of Bio-corrosion with Immersion Test}

In the bar chart of Fig. 8 can be seen that the highest corrosion rate is on ASTM A53 material without heat treatment with the addition of bacteria $\mathrm{T}$. ferrooxidans amounted to $3.63 \mathrm{mpy}$. As for the material with the addition of E. coli bacteria the corrosion rate is only $2.59 \mathrm{mpy}$. The difference from the addition of both bacteria is $1.33 \mathrm{mpy}$. This needs to be considered when the material will be used in the real operation.

T. ferrooxidans bacteria capable of degrading over steel because these bacteria produce more organic acids, pigments, ligands and $\mathrm{H} 2 \mathrm{~S}$. These substances act of removing heavy metal ions from solution than that of the E. coli bacteria on steel ASTM A53 [11].

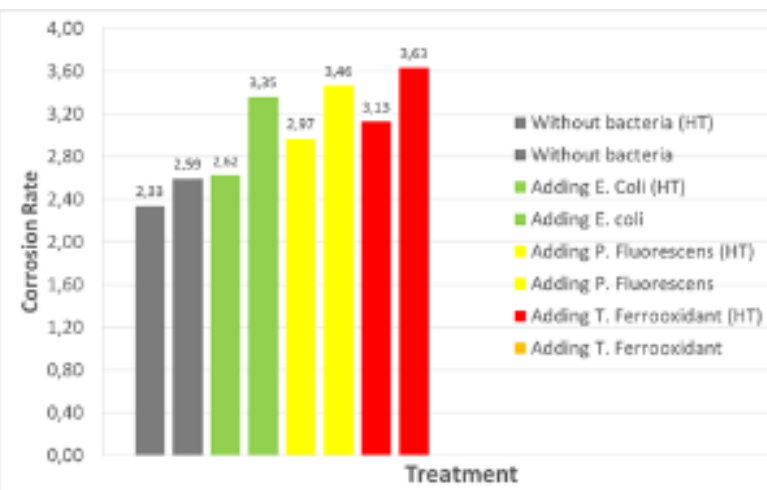

Figure 8. Bar chart comparison of the corrosion rate in steel ASTM A5

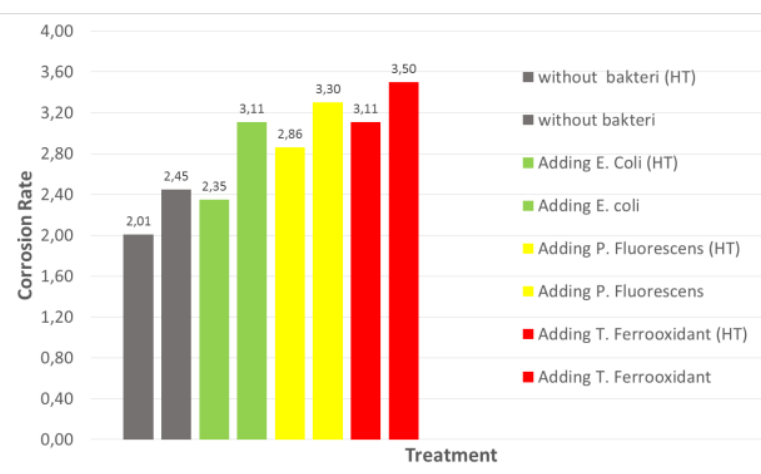

Figure 9. Bar chart comparison of the corrosion rate in steel API 5L

In Fig. 9, the bar chart exhibits the highest corrosion rate of the material API 5L occurs on the specimen without heat treatment with the addition of bacteria T. Ferrooxidans, that is at $3.50 \mathrm{mpy}$. As for the material by the addition of E. coli bacteria the corrosion rate is $2.01 \mathrm{mpy}$. The difference from the addition of both bacteria is $1.49 \mathrm{mpy}$. Again, this needs to be considered when the material will be used in a real operation.

Compared with ASTM A53 steel material, the steel material API 5L has a lower corrosion rate. This means that the steel API 5L is better and more capable to withstand the corrosion of bacteria than ASTM A53.

\subsection{Results of Microstructure Photograph}

As can be seen in Fig. 10 of the microstructure photograph results, in the area between the grain boundaries are seen a distinct pattern due to the effect of anode and cathode. Godard [12] states that in the cell, grain boundary area can be considered voltage because the atoms are not in a stable state or lowest energy. Black spots which exist in the center of the manganese sulfide grains are randomly scattered across the surface of the material. The presence of manganese sulfide and silicon tends to reduce the rate of corrosion.

Because in this study using rapid cooling, carbon will precipitate when less cooling rapidly that chromium carbide precipitates formed more would cause the area around the boundary will be deficient in chromium-free. This leads to the formation of a protective layer against corrosion, ie. the chromium oxide ( $\mathrm{Cr} 2 \mathrm{O} 3)$. So around the grain boundary corrosion will occur between the grains.

Figures 10 (i), (ii) and (iii) are microstructure photographs for ASTM A53, while Figs. 10 (iv), (v) and (vi) are for API 5L.It is visible on the surface of the steel material, grain boundary corrosion and pitting occur. Figures 10 (ii), (iii), (v) and (vi) showing the images of more corroded surface materials in comparison to Figs. 10 (i) due to the addition of bacteria. Figures 10 (iii) and (vi) illustrate the corrosion pattern on material without heat treatment.

Colonies of bacteria forming a layer (biofilm) on the surface of the material so that the material becomes corroded as a result of the activity of the living microorganisms. Biofilm which causes pitting corrosion are indicated by red circles. The grain boundary corrosion (intergranullar) is indicated by the red arrows. The microstructural photograph displays some parts of the grain boundaries which are visible as thick as an indication of corrosion between the grains happens more intensively. This is because in the Fig. 10 (iii) and (vi), the material is without heat treatment and the addition of bacteria enhance corrosion media, and hence the grain boundary corrosion occurs more.

\subsection{Results of Macrostructure Photograph}

Corrosion patterns on the materials under current study as the results of macrostructure photograph are displayed in Figs. 11 (i)-(iv). Visible on the surface of the steel material ASTM A53 pitting corrosion or pitting occurs with extensive marked of rough surfaces and potholes with golden yellow color indicated by the red circle. Figure 11 (i) shows more corroded surface than that in Fig. 11 (ii). Likewise Fig. 11 (iii) shows the more corroded surface than in Fig. 11 (iv). These suggest that $\mathrm{T}$. ferrooxidans bacteria induce more corrosion in comparison to E. coli bacteria.

Colonies of bacteria forming a layer (biofilm) on the surface of the material so that the material becomes corroded as a result of the activity of the living microorganisms. 
Biofilms are bacterial colonies or place that causes pitting corrosion to develop shown by the red circles. Pitting corrosion occurred on almost the entire surface of the specimen intensified due to immersed corrosion test.

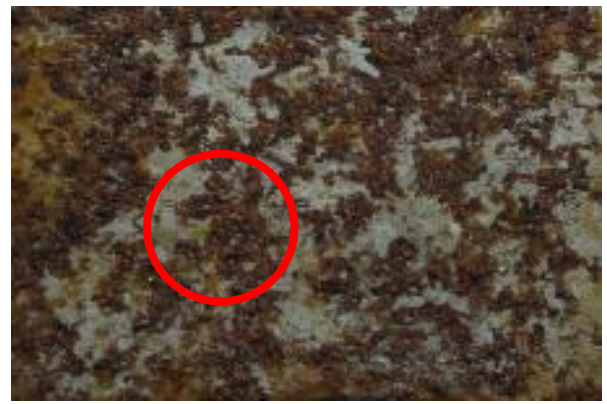

Figure 9. (i) ASTM A53 (HT) in sea water with addition of $\mathrm{T}$. ferrooxidans

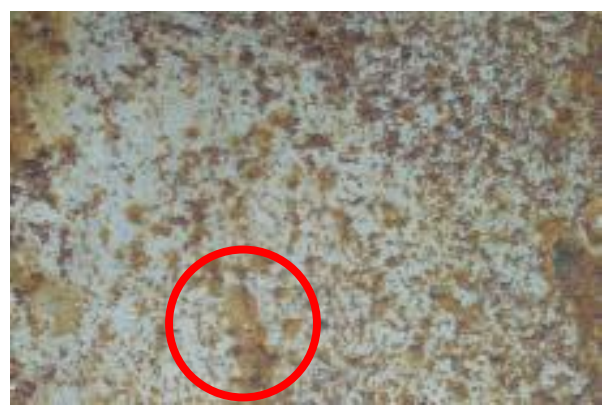

Figure 9. (ii) ASTM A53 (HT) in sea water with addition of E. coli

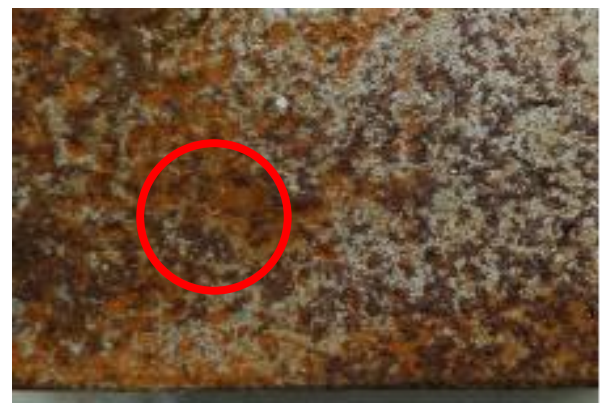

Figure 9. (iii) API 5L (HT) in sea water with addition of T. ferrooxidans

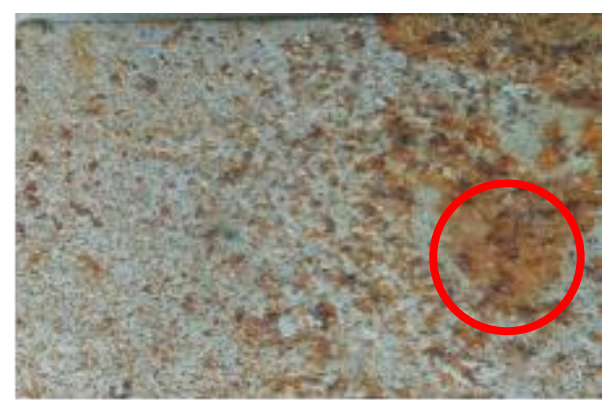

Figure 9. (iv) API 51 (HT) in sea water with addition of E. coli

\section{CONCLUSIONS}

An experimental study on the effect of heat treatment and types of bacteria on corrosion resistance of two types steel material, namely API 5L and ASTM A53, in Marine Environment has been conducted. This study concludes:

- Heat treatment proves to be effective in decreasing the rate of corrosion for both materials in artificial sea water with $35 \%$ salinity. When no bacteria presence, the corrosion rates of ASTM A53 and API 5L materials with heat treatment are, respectively, as low as 2.33 mpy and $2.01 \mathrm{mpy}$.

- Activities of bacteria on material surface produce a layer or biofilm, which in turn cause the pitting corrosion and grain boundary corrosion to occur.

- Highest corrosion rates take place when non-heat treated materials are induced by $\mathrm{T}$. ferrooxidans bacteria, in the order of 3.63 mpy and 3.50 mpy for ASTM A53 and API 5L, respectively. Correspondingly the E. coli bacteria yields 2.59 mpy and $2.01 \mathrm{mpy}$. Hence the effect of $\mathrm{T}$. ferrooxidans on both steel materials is found to be more aggressive if compared to E. coli.

- Overall results reveal a lower corrosion rate of the material API 5L steel in relation to ASTM A53. This suggest the steel pipe material selection can be said to be dependent on the condition of sea water where subsea pipelines are to be installed.

- Finally, the steel material API 5L is considered better for use in sea water containing bacteria than ASTM A53.

\section{ACKNOWLEDGEMENTS}

The authors are grateful to the management of the Laboratory of Structural Dynamics, Department of Ocean Engineering, and the Laboratory of Environmental Remediation, Department of Environmental Engineering, at ITS, Surabaya.

\section{REFERENCES}

1. ASM Handbook Vol.13A: Corrosion: Fundamental, Testing, and Protection. USA, 2003

2. Rheinheimer, G.: Aquatic Microbiology 4th Ed. John Willey and Sons, Chichester, 1991

3. Irianto, A. and Hendrati, P.M.: Biodiversity of aerobic heterotrophic bacteria from Baron beach, Gunung Kidul, Yogyakarta. Biodiversitas, V.4, N.2, pp. 80-82, July, 2003. DOI: 10.13057/biodiv/040202

4. Ugochukwu, C.O. and Sunday, I.: Cow urine effectiveness in control of microbially induced corrosion on oil transmission pipelines. Int. J. Eng. Innovative Technol., 3: 192-196, 2014 
5. Pratikno, H. and Titah, H.S.: Bio-corrosion on steel structure (ASTM A106 and A53) in marine environment. Asian Journal of Applied Sciences, V9, I3, pp. 120-125, 2016

6. Pratikno, H.: Mechanical testing to know influence of material thickness for Aisi 4340 steel austemper processing. Jurnal Teknologi Industri Vol. XI No.1: 7784, Jan. 2007

7. Budinski, K.G.: Engineering Materials: Properties and Selection, $5^{\text {th }}$ Ed. Prentice Hall inc., Englewood Cliffs, 1996

8. Harley, J.P. and Prescott, L.M.: Laboratory Exercises in Microbiology, $5^{\text {th }}$ Ed. McGraw Hill, New York, 2002
9. ASTM: Standard specification for substitute ocean water. Standards for Corrosion Testing of Metals ASTM DI 141-90. American Society for Testing and Materials, Philadelphia, 1994

10. ASTM: Standard Practice for Laboratory ASTM G3172. American Society for Testing and Materials, Philadelphia, 2004

11. Isa, I. dan Yuliana R.: Pemanfaatan berbagai jenis bakteri dalam proses bioleaching limbah logam berat. Laporan Tahunan Penelitian Fundamental, Universitas Negeri Gorontalo, 2013

12. Godard, H.P.: Localized corrosion. NACE Basic Corrosion Course. Houston, Texas, 1969 